\title{
Simultaneous Quantitation of Manganese (II) and Iron (III) In An Industrial Effluent Using Differential Pulse Polarography
}

\author{
S.T.Trivedi ${ }^{* 1}$, P.A.Sathe ${ }^{2}$ \\ (Department Of Chemistry, Ramnarain Ruia College, Matunga, Mumbai-19. INDIA)
}

\begin{abstract}
In the present study, a successful attempt has been made to develop a simple method for the simultaneous determination of manganese (II) and iron (III) in an industrial effluent using differential pulse polarography (DPP) technique. Quantification of manganese (II) and iron (III) was done in Triethanolamine and $\mathrm{KOH}$ as a supporting electrolyte. The polarogram recorded for the industrial effluent in triethanolamine and $\mathrm{KOH}$ showed two peaks at $-0.3 \mathrm{~V}$ and $-0.82 \mathrm{~V}$ vs. saturated calomel electrode which were confirmed to be of manganese (II) and iron (III) respectively by the method of standard addition. The linear working range for manganese (II) and iron (III) both was $1.408 \mu \mathrm{g} / \mathrm{mL}$ to $4.977 \mu \mathrm{g} / \mathrm{mL}$. The proposed method was found to be simple, precise, and accurate and can be successfully applied for the analysis and simultaneous determination of manganese (II) and iron (III) in industrial effluents.
\end{abstract}

Keywords: Differential pulse polarography, Industrial effluent, Iron (III), Manganese (II), Potassium hydroxide, Triethanolamine,

\section{Introduction}

Rapid industrialization and abnormal population growth has enhanced water pollution. Monitoring the metal ions and organic compounds in aquatic environment has been a subject of great concern over the last few decades and will continue to be so, as increasing number of metal ions in increasing amounts and a diverse array of organic compounds form a part of an industrial effluent. The heavy metals like Lead, Cadmium, Mercury, Arsenic, Iron, Nickel, Copper and others are used widely in industries. Thus, monitoring of these toxic substances is an integral part of environmental management. Some of these elements may be micronutrients for many living organisms and are required in small amounts for normal healthy growth, but any metal ion in large amount will always cause acute or chronic toxicity.

Manganese is an essential trace mineral. The mineral is considered to be essential for the formation of healthy red blood cells, proper pituitary gland function, and the maintenance of good eyesight. Manganese is not only necessary for humans to survive, but it is also toxic when too high concentrations are present in a human body.

Iron is a dietary requirement for most organisms. In small quantities, certain metals are nutritionally essential for a healthy life. These elements are also found in commercially available multivitamin products. Water soluble binary iron compounds such as $\mathrm{FeSO}_{4}, \mathrm{FeCl}_{2}$ may cause toxic effects with exceeding concentrations.

The present paper deals with simultaneous quantitation of such electroactive species which are commonly associated with effluents from pharmaceutical industries. Potentiometric stripping analysis of simultaneous determination of metal ions has been reported ${ }^{[1]}$. Polarographic determination of manganese in estuarine water has been studied ${ }^{[2]}$.Trace analysis of iron in environmental water and snow samples from Poland has been reported ${ }^{[3]}$. Simultaneous determination of trace metals in industrial and domestic effluents and other water samples by differential pulse anodic stripping voltammetry has also been reported ${ }^{[4,6]}$. Metals present in industrial effluents and sludge samples have been separated and concentrated by using other techniques like electrodialysis, coulometry and photocatalysis ${ }^{[9]}$. However, less work has been done in the area of environmental chemistry especially on separation and quantitation of electroactive species present in industrial effluents.

\section{Objective}

The main objective of the study was to provide a simple, rapid, efficient, precise and economical method for the simultaneous determination of $\mathrm{Mn}$ (II) and $\mathrm{Fe}(\mathrm{III})$ from an industrial effluent using differential pulse polarography. The developed method has been validated as per ICH guidelines ${ }^{[7-8]}$ 


\section{Materials and Methods (Experimental)}

3.1 Introduction to the workstation
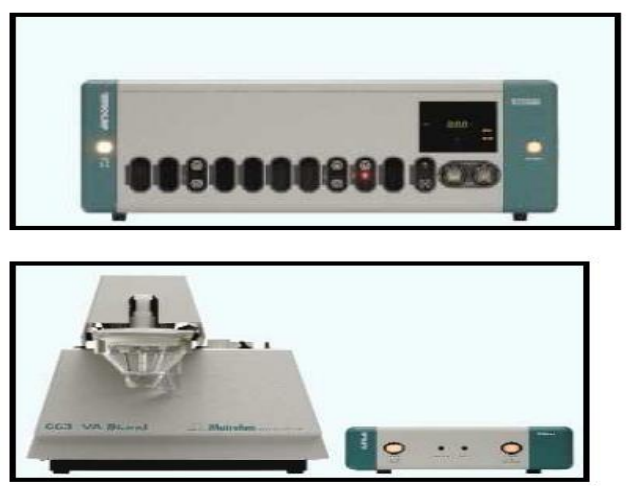

All the measurements were performed on a fully automated computerized electroanalytical workstation, an electrochemical system PG STAT 30 with 663 VA electrode stand manufactured by Metrohm. It includes 3 electrode system viz. hanging mercury drop electrode as a working electrode, saturated calomel electrode as a reference electrode and platinum electrode as an auxiliary electrode.

\subsection{Reagents}

Merck A.R grade Manganese sulphate, Ammonium iron (III) sulphate hexahydrate, Triehanolamine and Potassium hydroxide were used.

Preparation of Standard Solution

$30.8 \mathrm{mg}$ of $\mathrm{MnSO}_{4} \cdot \mathrm{H}_{2} \mathrm{O}$ and $86.3 \mathrm{mg}$ of Ammonium iron(III) sulphate were accurately weighed and dissolved in minimum amount of double distilled water, acidified with $0.1 \mathrm{~mL}$ of conc $\mathrm{HCl}$ and made up to the mark in $100 \mathrm{~mL}$ volumetric flask. The solutions so prepared contained $100 \mu \mathrm{g} / \mathrm{mL}$ of $\mathrm{Mn}$ (II) and $\mathrm{Fe}(\mathrm{III})$ respectively. All the other standard solutions containing $\mathrm{Mn}$ (II) and $\mathrm{Fe}(\mathrm{III})$ were prepared using this stock solution.

Preparation of sample solution

The sample was an effluent from a pharmaceutical industry. The sample solution was centrifuged and filtered through Whatman paper no. $41.50 \mathrm{~mL}$ of the sample was evaporated to dryness and extracted with water containing $0.2 \mathrm{~mL}$ of conc $\mathrm{HCl}$ and diluted to $100 \mathrm{~mL}$ in a volumetric flask with distilled water. Polarograms for the sample solutions were recorded under the same conditions used for the calibration curve. The amount of $\mathrm{Mn}$ (II) and $\mathrm{Fe}(\mathrm{III})$ were calculated from the measured peak currents and using the equation of the calibration curve. The equation of the calibration curve for $\mathrm{Mn}(\mathrm{II})$ was $\mathrm{y}=33.2262 \mathrm{x}-27.2592$ and for $\mathrm{Fe}$ (III) was $\mathrm{y}=33.3707 \mathrm{x}+0.8545$ where $\mathrm{y}$ is the current in $\mathrm{nA}$ and $\mathrm{x}$ is the concentration in $\mu \mathrm{g} / \mathrm{ml}$

\section{Voltammetric method}

$20 \mathrm{~mL}$ of Triethanolamine $(0.3 \mathrm{M})$ and $0.1 \mathrm{~mL}$ of $\mathrm{KOH}(0.1 \mathrm{M})$ was placed in the dry, clean voltammetric cell. The solution was purged with pure nitrogen gas for $180 \mathrm{~s}$. The potential scan between $0 \mathrm{~V}$ to $2.0 \mathrm{~V}$ vs. S.C.E was applied. The operational parameters were as follows: 1] Scan rate- $15 \mathrm{mVs}^{-1 .}$ 2] Pulse amplitude- $50 \mathrm{mV}$. After recording a polarogram of the blank, $0.1 \mathrm{~mL}$ of standard solutions of $\mathrm{Mn}$ (II) and $\mathrm{Fe}(\mathrm{III})$ were added in succession and polarograms were recorded and peak currents were measured and calibration curves were prepared.

\subsection{System Suitability}

\section{Analytical Method validation}

System suitability tests were carried out to ensure reproducibility of the instrument. The system suitability test was carried out by recording polarogram for Mn (II) and Fe (III) at one concentration (3.2258 $\mu \mathrm{g} / \mathrm{ml}$ for $\mathrm{Mn}(\mathrm{II})$ and $\mathrm{Fe}(\mathrm{III}))$ with five replicates and the mean current was used for the calculation. The \% RSD in all the cases was found to be less than $2 \%$.

\subsection{Specificity}

The specificity of method was confirmed by comparing the polarograms of the standard solutions containing $\mathrm{Mn}$ (II) and $\mathrm{Fe}(\mathrm{III})$ with the sample solution. The peak potentials recorded for the sample solution were found to be identical to those obtained for the combined standard solution of $\mathrm{Mn}$ (II) and $\mathrm{Fe}(\mathrm{III})$. The addition of the standard solutions of $\mathrm{Mn}$ (II) and $\mathrm{Fe}(\mathrm{III})$ to the sample solution did not change the 
characteristics of differential pulse polarogram but enhanced the peak current. This confirms the specificity of the method.

\subsection{Robustness}

The robustness of the method was examined by observing the consistency of the peak height and the peak shape with the deliberately made small changes in the experimental parameters. It is a measure of the capacity of the method to remain unaffected by small, but deliberate variations in method parameters and provides an indication of its reliability during normal usage. To determine the robustness of the proposed method, the following variations were made in the analytical parameters. The Scan rate was changed by \pm 0.5 $\mathrm{mVs}^{-1}$ and the Pulse amplitude $\pm 1.0 \mathrm{mV}$ These parameters were deliberately changed one at a time and the effect of these changes on the peak shape and peak currents were studied. The proposed method was found to be robust.

\subsection{Linearity and Dynamic range}

The linearity for $\mathrm{Mn}$ (II) and $\mathrm{Fe}(\mathrm{III})$ in a solution containing the two was determined. In the concentration range $1.408 \mu \mathrm{g} / \mathrm{mL}$ to $7.079 \mu \mathrm{g} / \mathrm{mL}$ for $\mathrm{Mn}$ (II) and $1.408 \mu \mathrm{g} / \mathrm{mL}$ to $6.25 \mu \mathrm{g} / \mathrm{mL}$ for $\mathrm{Fe}$ (III) a good linearity was obtained. The equation of the calibration curves is presented in (Table1).

\subsection{Limit of Detection and Limit of Quantitation}

The limit of detection (LOD) and the limit of quantification (LOQ) for Mn(II) and Fe(III) were fixed at signal tonoise ratio of 3:1 and 10:1 respectively. Twenty replicates of the blank solution were recorded and the mean current value at the peak potential of $\mathrm{Mn}(\mathrm{II})$ (i.e. at $-0.3 \mathrm{~V}$ ) and $\mathrm{Fe}(\mathrm{III})$ (i.e. at $-0.82 \mathrm{~V}$ ) were calculated. The concentration at which the peak current was found three times of mean blank current was taken as the limit of detection and the concentration at which peak current was found to be ten times the mean blank current was selected as the limit of quantification. The LOD and LOQ of Mn(II) and Fe(III) were $0.943 \mu \mathrm{g} / \mathrm{mL}$ and 1.408 $\mu \mathrm{g} / \mathrm{mL}$ and $0.474 \mu \mathrm{g} / \mathrm{mL}$ and $1.408 \mu \mathrm{g} / \mathrm{mL}$ respectively.

\subsection{Intra-day and Inter-day Precision}

The variability of the method was tested with the intra-day and inter-day precision. It was checked by recording the polarograms of standard solutions of $\mathrm{Mn}$ (II) and $\mathrm{Fe}(\mathrm{III})$ in the concentration ranges $1.408 \mu \mathrm{g} / \mathrm{mL}$ to $4.977 \mu \mathrm{g} / \mathrm{mL}$ for $\mathrm{Mn}$ (II) and $\mathrm{Fe}(\mathrm{III})$. Intra-day precision was tested by recording the polarograms at an interval of four hours and inter-day precision twice a day with a gap of three days. The mean \% RSD for intraday and inter-day precision for $\mathrm{Mn}$ (II) $0.92 \%$ and $1.44 \%$ and for $\mathrm{Fe}(\mathrm{III}) 0.98 \%$ and $1.61 \%$ respectively.

\subsection{Quantitation / Determination}

The validated method was used for the determination of $\mathrm{Mn}$ (II) and Fe(III). Polarograms were recorded under the optimum experimental conditions for the sample solution. Resulting peak currents for $\mathrm{Mn}$ (II) and $\mathrm{Fe}(\mathrm{III})$ were measured and the amount of $\mathrm{Mn}$ (II) and $\mathrm{Fe}(\mathrm{III})$ was calculated using calibration curve equations. The results are presented in (Table 2).

\subsection{Accuracy (Recovery)}

The recovery technique was used to evaluate the accuracy of the method. The method of standard addition was employed for the purpose. A fixed volume of the standard $\mathrm{Mn}$ (II) and Fe(III) solution was added to the sample solutions and the mixed solutions so obtained were analyzed by the proposed method. The percentage recovery was determined at different percentage levels i.e. the added amounts ranging from $40 \%$ to $140 \%$ of the amount present in the sample. The results of the recovery analysis for $\mathrm{Mn}$ (II) and $\mathrm{Fe}$ (III) are presented in

(Table 3)

\section{Results and Discussion}

The present study provides determination of $\mathrm{Mn}(\mathrm{II})$ and $\mathrm{Fe}(\mathrm{III})$ from the industrial effluents using the technique of differential pulsepolarography. The method was validated as per the ICH guidelines (Table 1-3). Before validation, optimization of the conditions i.e. $\mathrm{pH}$, supportingelectrolyte,scan rate and pulse amplitude were optimized. The polarographic response of the sample for $\mathrm{Mn}$ (II) and $\mathrm{Fe}$ (III) in different supporting electrolytes has been studied. With $\mathrm{KCl}$ as the supporting electrolyte the sample showed one broad merged peak for $\mathrm{Mn}(\mathrm{II})$ and $\mathrm{Fe}(\mathrm{III})$. However, separate peaks were produced with Triethanolamine and $\mathrm{KOH}$ as the supporting electrolyte.

Pulse amplitude of $50 \mathrm{mV}$ was chosen as the optimum as there is loss of resolution at high pulse amplitude and with low pulse amplitude the current obtained was low. The Differential Pulse Polarogram of 
$\mathrm{Mn}$ (II) and Fe(III) were recorded at various scan rates. At scan rates higher than $15 \mathrm{mVs}^{-1}$ the width of peak increases, its height decreases and peak shape was distorted. At lower scan rates than $15 \mathrm{mVs}^{-1}$ peak current was lower. So a scan rate of $15 \mathrm{mVs}^{-1}$ was chosen as a best for the analysis.

Table 1: METHOD VALIDATION PARAMETERS FOR MANGANESE (II) AND IRON (III)

\begin{tabular}{|c|c|c|}
\hline Parameters & \multicolumn{2}{|c|}{ Values } \\
\hline & Mn(II) & Fe(III) \\
\hline $\begin{array}{c}\text { System suitability }(\mathrm{n}=5) \\
\% R S D\end{array}$ & $0.72 \%$ & $0.96 \%$ \\
\hline Linearity range $(\mu \mathrm{g} / \mathrm{ml})$ & 1.408 to $4.977 \mu \mathrm{g} / \mathrm{ml}$ & 1.408 to $4.977 \mu \mathrm{g} / \mathrm{ml}$ \\
\hline Slope $(\mathrm{m})^{\text {a) }}$ & 33.2622 & 33.3707 \\
\hline Intercept $(\mathrm{c})^{\text {a) }}$ & -27.2592 & 0.8545 \\
\hline${\text { Correlation coefficient }\left(\mathrm{R}^{2}\right)}^{\text {LOD }(\mu \mathrm{g} / \mathrm{ml})}$ & 0.9992 & 0.9991 \\
\hline LOQ $(\mu \mathrm{g} / \mathrm{ml})$ & $0.943 \mu \mathrm{g} / \mathrm{ml}$ & $0.474 \mu \mathrm{g} / \mathrm{ml}$ \\
\hline Intraday precision $(\mathrm{n}=5)$ & $1.408 \mu \mathrm{g} / \mathrm{ml}$ & $1.408 \mu \mathrm{g} / \mathrm{ml}$ \\
\hline Interday precision $(\mathrm{n}=5)$ & $0.92 \%$ & $0.98 \%$ \\
\hline Recovery & $1.44 \%$ & $1.61 \%$ \\
\hline
\end{tabular}

a) Of the equation $y=m x+c$, where $y$ is peak current, $m$ is the slope, $x$ is the concentration and $c$ is the intercept

Table 2: RESULTS OF QUANTITATION STUDIES FOR MANGANESE (II) AND IRON (III)

\begin{tabular}{|c|c|c|}
\hline $\begin{array}{c}\text { Name of Metal } \\
\text { ions }\end{array}$ & Mn (II) & Fe (III) \\
\hline Conc in $\mu \mathrm{g} / \mathrm{ml}$ & 345.2 & 472.8 \\
\hline$\%$ RSD $(\mathrm{n}=5)$ & 0.55 & 0.64 \\
\hline
\end{tabular}

Table 3.RESULTS OF RECOVERY STUDIES FOR MANGANESE (II) AND IRON (III)

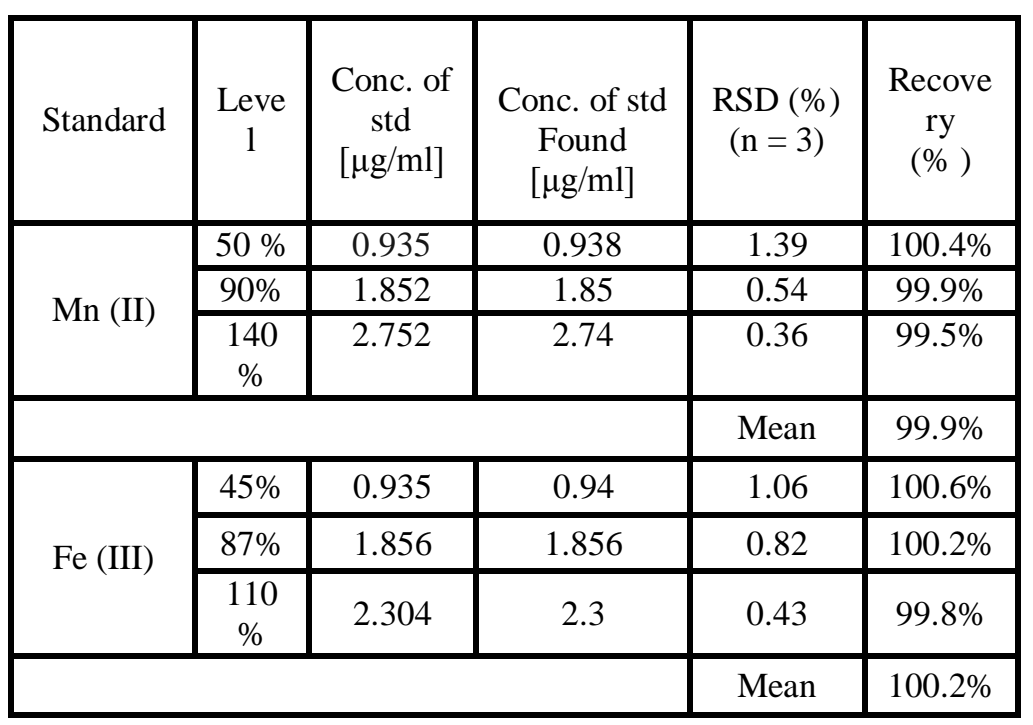




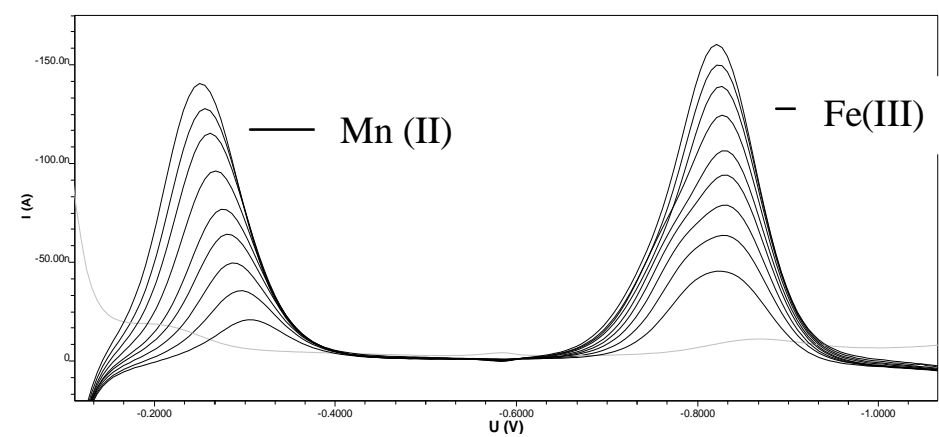

Figure-2.LINEARITY GRAPHES FOR MANGANESE (II) AND IRON (III)

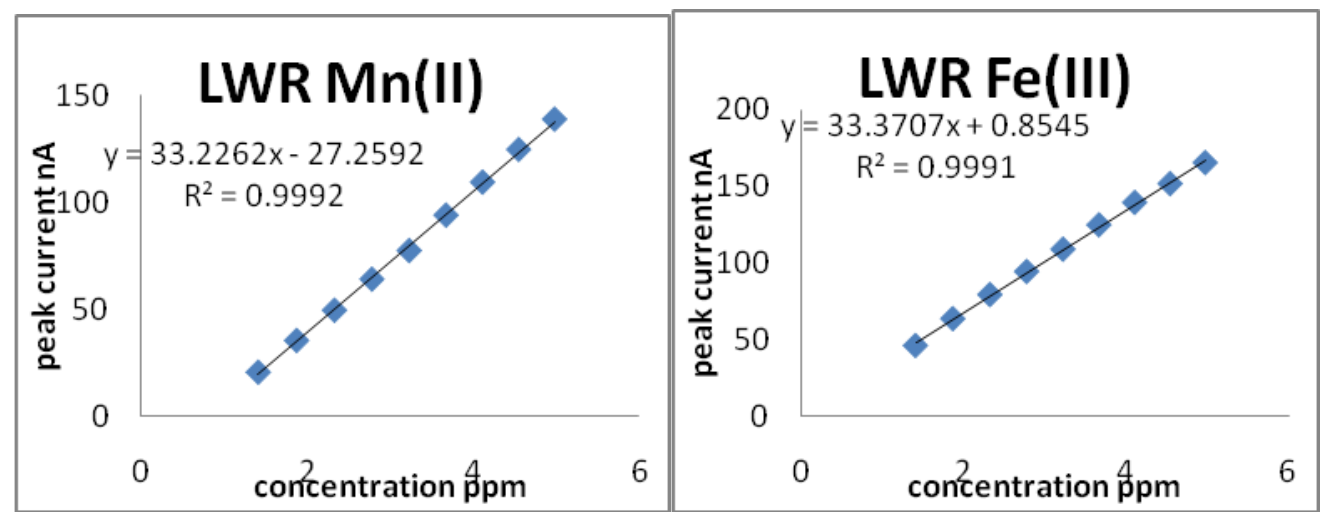

LWR: Linear working range ppm: $\mu \mathrm{g} / \mathrm{ml}$

VII. Acknowledgement

We thank the Department of Chemistry and Ruia College (Matunga Mumbai-19 India) for providing us with the necessary research facilities.

\section{References}

[1] Sun Qinshu,Hou Shifeng, Chen Zhongdao, Zhu Jun; Potentiometric Stripping Analysis for Simultaneous Determination of Copper, Lead, Cadmium, Zinc, Iron and Manganese. Chinese Journal of Analytical Chemistry CNKI:SUN:FXHX.0.1994-05-015

[2] S. Knox, D. R. Turner; Polarographic measurement of Manganese (II) in estuarine water. Estuarine and Coastal Marine Science $10(3), 317-324$

[3] Jerzy Golimowski; Trace Analysis of Iron in Environmental Water and Snow Samples from Poland. Analytical Letters. Taylor and Francis 22 (2), 1989, 481-492.

[4] J. Gardiner, M.J. Stiff; The determination of cadmium. lead, copper and zinc in ground water, estuarine water, sewage and sewage effluent by anodic stripping voltammetry. Water research 9 (5-6), 1975, 517-523.

[5] Raluca Ioana Stefana, Semere Ghebru Bairua \& Jacobus Frederick van Staden; Determination of Fe(III) Using Diamond Paste Based Electrodes Preview. Instrumentation Science \& Technology. Taylor and Francis 31 (4), 2003, 411 - 416.

[6] James T. Kinard; Simultaneous determination of Trace metals in Industrial and Domestic Effluents by Differential Pulse Anodic Stripping Voltammetry. Jounal of Environmental Science and Health. Taylor and Francis 12 (10), 1977, 531-547

[7] ICH, Q2A, Validation of Analytical Procedure: Methodology, In. Proc.Int.Con. Harmonization, Geneva 1994.

[8] ICH Q2B, Validation of Analytical Procedure: Methodology, In. Proc. Int. Con. Harmonization, Geneva 1996.

[9] G. Ramachandraiah, S. K. Thampy, P. K. Narayanan, D. K. Chauhan, N. NageswaraRao, V. K. Indusekhara; Separation and Quantitation of metals present in industrial effluents and sludge samples by electrodialysis, coulometry and photocatalysis. Separation Science and Technology 31, 1996, 523 - 532. 